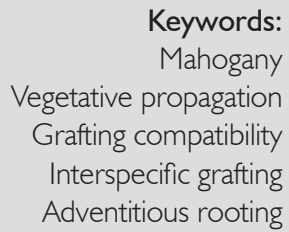

Histórico:

Recebido 16/09/2016 Aceito 18/1 1/2016

Palavras chave: Mogno

Propagação vegetativa Compatibilidade do enxerto Enxertia interespecífica Enraizamento adventício

${ }^{+}$Correspondência: gebrondani@yahoo.com.br

DOI:
Joamir Barbosa Filho', Maria Angélica Di Carvalho', Leandro Silva de Oliveira², Enéas Ricardo Konzen ${ }^{3}$, Wellington Ferreira Campos ${ }^{4}$, Gilvano Ebling Brondani ${ }^{3+}$

\section{PROPAGATION OF KHAYA ANTHOTHECA: INTERSPECIFIC GRAFTING WITH SWIETENIA MACROPHYLLA AND AIR LAYERING}

ABSTRACT: Swietenia macrophylla yields high-quality wood; however, its vulnerability to extinction coupled with challenges for its cultivation have brought attention to its replacement for alternative species such as the Khaya anthotheca. The species has been recently introduced to South America, with potential for the production of high-quality wood. However, limited background on breeding and efficient strategies for its vegetative propagation exist. Here, we achieved significant results with the application of cleft grafting and air layering for the propagation of $K$. anthotheca plants grown from seeds. First, we analyzed the compatibility of scions and rootstocks for intraspecific and interspecific cleft grafting combinations of $K$. anthotheca and S. macrophylla. Second, air layering was performed in K. anthotheca seedlings irrigated with three nutrient solution (100\%, $50 \%$ and $25 \%$ of the initial concentration of nutrients) combined with the application of indole-3-butyric acid (IBA) to evaluate adventitious rooting. From cleft grafting, we achieved an overall graft compatibility and survival of $48 \%$ after 200 days. However, the interspecific combination of S. macrophylla (scion) and $K$. anthotheca (rootstock) implicated in no compatibility, while the reciprocal resulted in $52 \%$ of compatibility. Through air layering, the irrigation with the nutrient solution with at least $50 \%$ of the nutrients concentration and with IBA $\left(3.0\right.$ or $\left.8.0 \mathrm{~g} \cdot \mathrm{L}^{-1}\right)$ resulted in the best adventitious rooting. Overall, we recommend cleft grafting, except for the combination S. macrophylla (scion) and $K$. anthotheca (rootstock), with no compatibility. Air layering might also be useful for the propagation of $K$. anthotheca genotypes in breeding programs.

\section{PROPAGAÇÃO DE KHAYA ANTHOTHECA: ENXERTIA INTERESPECÍFICA COM SWIETENIA MACROPHYLLA E MERGULHIA AÉREA}

RESUMO: Swietenia macrophylla é uma espécie que fornece madeira de alta qualidade, no entanto, sua vulnerabilidade à extinção somada aos desafios para seu cultivo tem despertado a atenção para novas alternativas, como a Khaya anthotheca. A espécie foi recentemente introduzida na América do Sul, mostrando potencial para a produção de madeira de alta qualidade. No entanto, informações sobre o melhoramento são limitadas, assim como estratégias para a propagação vegetativa. No presente trabalho foram obtidos resultados significativos da aplicação da enxertia por garfagem e da mergulhia aérea na propagação de $K$. anthotheca. Primeiramente, foi analisada a compatibilidade entre enxerto e porta-enxerto em combinações intra e interespecíficas entre $K$. anthotheca e S. macrophylla. Adicionalmente, a mergulhia aérea foi realizada em plantas de $K$. anthotheca irrigadas com três soluções nutritivas ( $100 \%$, 50\% e $25 \%$ da concentração original) combinadas com a aplicação de ácido indolbutírico (AIB) para avaliação do enraizamento. Da enxertia, foi verificada compatibilidade de $48 \%$ após 200 dias. No entanto, a combinação interespecífica entre $K$. anthotheca (portaenxerto) e S. macrophylla (enxerto) não apresentou compatibilidade, enquanto que a enxertia recíproca resultou em $52 \%$ de compatibilidade. Através da mergulhia aérea, a irrigação com pelo menos $50 \%$ da concentração de nutrientes e combinada com a aplicação de AIB (3,0 ou $8,0 \mathrm{~g} \cdot \mathrm{L}^{-1}$ ) resultou na melhor performance de enraizamento. No geral, recomenda-se a enxertia por garfagem, exceto para a combinação S. macrophylla (enxerto) com K. anthotheca (porta-enxerto). A mergulhia aérea pode ser útil para a propagação de genótipos selecionados de $K$. anthotheca em programas de melhoramento genético.

' Federal University of Mato Grosso - Cuiabá, Mato Grosso, Brasil

${ }^{2}$ Federal University of Minas Gerais - Montes Claros, Minas Gerais, Brasil

${ }^{3}$ Federal University of Lavras - Lavras, Minas Gerais, Brasil

${ }^{4}$ Federal University of Jequitinhonha and Mucuri Valleys - Unaí, Minas Gerais, Brasil 


\section{INTRODUCTION}

Swietenia macrophylla King (Meliaceae) has been the most important source of high-quality wood among the mahoganies used in national and international markets. Most of mahogany wood has been obtained from natural populations in South and Central America, frequently from illegal extraction and trade. Thus, the populations of the species have been severely reduced, compromising the availability its genetic resources (WHITMORE, 2003; DEGEN et al., 20I3) and its survival and perpetuation (GROGAN; LOVELESS, 2013).

Despite several efforts in cultivating $S$. macrophylla for commercial purposes, a major issue has been the insect Hypsipyla grandella, which attacks the meristems of plants affecting most plantations (CORNELIUS, 200I; MOREIRA et al., 20I4; ROCHA et al., 2016). Such an issue, coupled with the ecological and genetic vulnerability of S. macrophylla, has motivated producers to introduce alternative species for providing wood with similar quality. In Brazil, Khaya anthotheca Welw. has been considered an option for replacing S. macrophylla. No reports on $H$. grandella incidence on $K$. anthotheca have been documented so far (PINHEIRO et al., 20I I).

K. anthotheca, commonly known as African mahogany, white mahogany or grand bassam mahogany, is a tropical species native to Africa, which yields wood of high standards for the international market (OPUNIFRIMPONG et al., 2008). Medicinal properties have also been reported, as limonoid extracts from $K$. anthotheca displayed potent antimicrobial activity (SULEIMANA et al., 2009) and antiprotozoal activity (OBBO et al., 20I3). Antioxidant properties have also been reported (SULEIMAN et al., 2010). A specific role in antimalarial activity has been reported for the limonoid anthothecol (LEE et al., 2008; MOYO et al., 2016). Anthothecol may also have a preclinical significance in the treatment and prevention of pancreatic cancer (VERMA et al., 20I5).

Despite the incentives for the introduction of K. anthotheca to Brazil, the availability of seeds and plants for field plantations are still low (PINHEIRO, $201 \mathrm{I}$; FRANÇA et al., 20I5). Furthermore, there is no established breeding program for the species in Brazil, nor a germplasm bank, which could be used toward selecting superior genotypes adaptable to Brazilian sites. One important step in constituting such a breeding program is to have established vegetative propagation techniques to propagate superior genotypes. Among the various vegetative propagation methods, air layering and grafting are low-cost and effective strategies to rescue superior materials, create seed orchards for producing seeds of desired genetic materials and obtain propagules for other techniques such as cuttings and mini-cuttings (HARTMANN et al., 20I I). The grafting technique consists of joining two or more parts of different plants. One is the rootstock, which serves as the support for the other part. The other is the scion, which generally consists of a branch, bud or other part of the plant. Grafting involves three major steps: adhesion between the rootstock and the scion; cicatrization and cellular proliferation; and tissue junction from vascular differentiation, which ultimately confer the graft union compatibility (HARTMANN et al., $20 \mathrm{II}$ ). Alternatively, air layering is aimed at promoting adventitious rooting on branches that are still connected to the main tree. The process is stimulated by plant growth regulators from the plant or artificially supplied, such as with the application of indole-3-butyric acid (IBA) (HARTMANN et al., 20I I).

Reports of the application of vegetative propagation methods on mahoganies are restricted to a few studies, such as with grafting of $S$. macrophylla and $K$. ivorensis (KALIL FILHO; HOFFMANN, 2008). The use of grafting with selected genotypes of $\mathrm{S}$. macrophylla has shown a potential reduction in the damage caused by $H$. grandella (PEREZ et al., 20I0a). Grafting has also been applied to the related mahogany $K$. senegalensis (NIKLES et al., 2008), as well as micrografting (DANTHU et al., 2003). Conversely, air layering has been scarcely used although it has been reported in Meliaceae family with Cedrela odorata (BRITWUM, 1970). To date, no report on the application of grafting or air layering has been published for $K$. anthotheca.

The present work was aimed at the implementation and adaptation of cleft grating and air layering techniques for $K$. anthotheca. We evaluated the efficiency of grafting and air layering from selected rootstocks and scions of plants obtained from seeds. Inter-specific grafting was performed with combinations between $K$. anthotheca and S. macrophylla. Histological analyses provided evidence of the graft union compatibility. Air layering was performed with different combinations of nutrient solutions and IBA application. This is the first report concerned with the application of such techniques to $K$. anthotheca.

\section{MATERIAL AND METHODS}

\section{Plant materials and location of the experiments}

Our experiments were conducted with seedlings from $K$. anthotheca and S. macrophylla, which were grown from seeds. The $K$. anthotheca seeds were imported by BioSementes $^{\circledR}$ (http://www.biosementes.com.br). The 
seeds originated from Gana, North Africa, and were imported according to Brazilian laws and registrations (RENASEM, BA0I04/20II). The seeds of S. macrophylla were obtained from selected trees at the Federal University of Mato Grosso, Mato Grosso, Brazil. Seedlings were grown in polyethylene bags containing substrate composed of dark soil (A horizon) and cattle manure $(I: I, v / v)$. After planting, the materials were kept in shade house ( $50 \%$ shade). Seedlings were irrigated with 10 g. $\mathrm{L}^{-1}$ NPK (4-14-8, N-P $\mathrm{O}_{5}-\mathrm{K}_{2} \mathrm{O}$ ) at intervals of 60 days.

The experiments were conducted at the N'tacua nursery, in Cuiabá, Mato Grosso, Brazil (15³5'56" S, $56^{\circ} 06^{\prime} 05^{\prime \prime} \mathrm{W}, 165 \mathrm{~m}$ altitude). This area has a tropical wet and dry climate $(A w)$, with rainy summers, as described by an updated Köppen's climate categorization (ALVARES et al., 20I3). The annual average temperature of this area is $25.8^{\circ} \mathrm{C}$. However, maximum temperatures occasionally reached $43^{\circ} \mathrm{C}$ during the experimental period.

\section{Cleft grafting}

Cleft grafting was performed by reciprocals union between selected scions and rootstocks from K. anthotheca and S. macrophylla plants, both with 280 days (after germination) (Figure IA). The following combinations (treatments) of scion and rootstock were conducted: K.A./S.M. = Khaya anthotheca + Swietenia macrophylla (scion/rootstock); S.M./K.A = Swietenia macrophylla + Khaya anthotheca (scion/rootstock); S.M./ S.M. = Swietenia macrophylla + Swietenia macrophylla (scion/rootstock); and K.A./K.A. = Khaya anthotheca + Khaya anthotheca (scion/rootstock). Seedlings with similar stem diameters were selected. The stock was cut in a smooth straight-grained section $(\mathrm{I}-2 \mathrm{~cm})$ evenly split at $15 \mathrm{~cm}$ from the base of the plant (contact with soil). The bottom of the scion was prepared by cutting a gradually tapering wedge of approximately $1.5 \mathrm{~cm}$. Leaves were detached from the scion to reduce evapotranspiration. The scion was inserted into the rootstock, aimed at joining their cambium regions. The cleft graft was then wrapped with a biodegradable plastic ribbon. Finally, the graft was covered with a yellow-brown paper bag $(5 \times 25$ $\mathrm{cm}$ ) fixed at $3 \mathrm{~cm}$ below of the insertion area. The grafted seedlings were maintained under greenhouse conditions for 45 days. Meanwhile, shoots grown out from the rootstocks were removed to promote the recovery of the cambial tissues from both scion and stock. After this period, the seedlings were transferred to a shade house and the grafting union compatibility (connection between cambial tissues) was evaluated after 45 and 200 days after the grafting procedure. All steps of the cleft grafting were performed with gloves and grafting pliers sanitized with sodium hydrochloride $25 \%(\sim 0.50$ $-0.62 \%$ of active chlorine).

The experiment was performed in a completely randomized block design with five replicates of each of the four combinations, i.e., treatments, between $K$. anthotheca and S. macrophylla. The experimental units consisted of plots with five cleft grafts for each treatment. In total, 100 grafts were used.

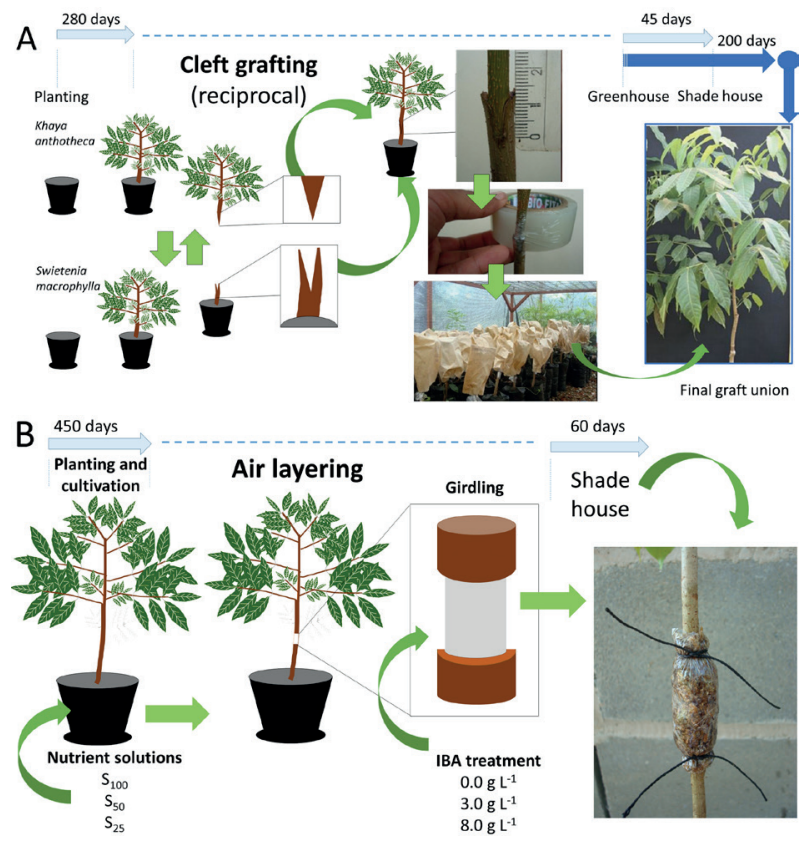

FIGURE I Schematic representation of the steps for grafting and air layering on Khaya anthotheca. A - Reciprocal cleft grafting between K. anthotheca and Swietenia macrophylla (scion $\leftrightarrow$ rootstock). B - Air layering of $\mathrm{K}$. anthotheca. $\mathrm{SIO0}=100 \%$ of the original concentration of macro and micronutrients (Table I); $S 50=50 \%$ of the original concentration; and $\mathrm{S} 25=25 \%$ of the original concentration.

\section{Air layering}

Air layering was performed on 450-day-old seedlings of $K$. anthotheca, that were approximately 40 $\mathrm{cm}$ height (Figure IB). The seedlings were transferred to cylindrical polyethylene bags $(3.8 \mathrm{~L})$. The substrate was composed by medium-sized washed sand $(0.10 \mathrm{~mm}<$ particle size $<0.25 \mathrm{~mm}$ ). The bottom of each pot was filled with a $3 \mathrm{~cm}$-layer of crushed stone. Leaf area was reduced by $50 \%$ to avoid effects of dehydration after transplantation; and roots were pruned.

The plants were maintained in a shade house (50\% shade). At 20 days after transplantation, the substrate of each pot was evenly irrigated between 7 and 8 a.m. with $100 \mathrm{~mL}$ of nutrient solution containing $100 \%\left(\mathrm{~S}_{100}\right), 50 \%\left(\mathrm{~S}_{50}\right)$ or $25 \%\left(\mathrm{~S}_{25}\right)$ of the macro and micronutrient solution provided in Table I. 
TABLE I Basic nutrient solution components for fertigation of Khaya anthotheca seedlings.

\begin{tabular}{|c|c|c|c|c|}
\hline Nutrient & $\begin{array}{c}\text { Concentration } \\
\left(\mathrm{mg} \cdot \mathrm{L}^{-1}\right)\end{array}$ & Source of macro and micronutrient & $\begin{array}{c}\text { Percentage } \\
(\%)\end{array}$ & $\begin{array}{c}\text { Concentration } \\
\left(\mathrm{mg} \cdot \mathrm{L}^{-1}\right)\end{array}$ \\
\hline $\mathrm{N}-\mathrm{NO}_{3}^{-}$ & 60.00 & Monoammonium phosphate & $11 \% \mathrm{NH}_{4}^{+} / 60 \% \mathrm{P}_{2} \mathrm{O}_{5}$ & 38.53 \\
\hline $\mathrm{N}-\mathrm{NH}^{3}+$ & 30.00 & Magnesium sulfate & $9 \% \mathrm{Mg} / \mathrm{I} 2 \% \mathrm{SO}^{2-5}$ & 133.33 \\
\hline $\mathrm{P}^{4}$ & 12.00 & Potassium nitrate & $13 \% \mathrm{NO}_{3}-12 \% \mathrm{P}_{2} \mathrm{O}_{5} / 44^{4} \% \mathrm{~K}_{2} \mathrm{O}$ & 219.03 \\
\hline $\mathrm{Ca}$ & 40.00 & Ammonium sulfate & $21 \% \mathrm{NH} 4+/ 22 \% \mathrm{SO}_{4}^{22^{2}}$ & 122.67 \\
\hline $\mathrm{K}$ & 80.00 & Calcium chloride & $27 \% \mathrm{Ca}$ & 8.78 \\
\hline S & 14.85 & Calcium nitrate & $15,5 \% \mathrm{NO}_{3} / 18,5 \% \mathrm{Ca}$ & 203.40 \\
\hline$M g$ & 12.00 & Boric acid & $17 \% \mathrm{~B}$ & 5.88 \\
\hline $\mathrm{Cu}$ & 0.10 & Manganese sulfate & $30 \% \mathrm{Mn} / 17 \% \mathrm{SO}_{4}^{2-}$ & 5.33 \\
\hline $\mathrm{Fe}$ & 2.00 & Sodium molibdate & $39 \%$ Мо & 0.05 \\
\hline Mo & 0.05 & Zinc sulfate & $20 \% \mathrm{Zn} / 10 \% \mathrm{SO}_{4}^{2-}$ & 5.00 \\
\hline$M n$ & 1.60 & Iron sulfate & $6 \% \mathrm{Fe}$ & 33.33 \\
\hline $\mathrm{Zn}$ & 1.00 & Copper sulfate & $25 \% \mathrm{Cu} / \mathrm{I} 2 \% \mathrm{SO}_{4}^{2-}$ & 0.40 \\
\hline B & 1.00 & - & - & - \\
\hline
\end{tabular}

The solution $\mathrm{pH}$ was adjusted to 5.8 at $25^{\circ} \mathrm{C}$ with $\mathrm{HCl}$ or $\mathrm{NaOH}$, both at I.0 M. Modified from Brondani et al. (20I4).

The air layering procedure was performed 60 days after irrigation with the nutrient solution was initiated. The complete stem-girdling method was employed in this study. Girdling was conducted at $15 \mathrm{~cm}$ from the base of each seedling. After girdling, the area was sprayed with indole-3-butiric acid (IBA) at the concentrations of 0.0 (control), 3.0 and $8.0 \mathrm{~g} \cdot \mathrm{L}^{-1}$. Thereafter, the girdled region was covered with sphagnum and isolated with a PVC plastic film. The air layers were moistened with $5 \mathrm{~mL}$ of water, using a syringe, every two weeks. After 60 days, the upper region from the air layers was removed since it presented the roots to be used for generating a newly separate plant. The procedures were performed with a switchblade knife sanitized with sodium hydrochloride at $25 \%$ ( $~ 0.50-0.62 \%$ of active chlorine).

The experiment was conducted as a completely randomized block design in factorial arrangement $(3 \times 3)$ with three replicates. The treatments consisted of the nutrient solutions $\left(\mathrm{S}_{100}, \mathrm{~S}_{50}\right.$ and $\left.\mathrm{S}_{25}\right)$ and three concentrations of IBA $\left(0.0,3.0\right.$ and $\left.8.0 \mathrm{~g} \cdot \mathrm{L}^{-1}\right)$. The experimental units consisted of plots with four plants per plot. At the end of the experiment, we evaluated the percentage of plants with adventitious rooting and the percentage of plants that formed callus (i.e., callogenesis).

\section{Histological analyses}

Samples of cambial tissue from the contact area between graft ( $K$. anthotheca) and rootstock (S. macrophylla) were collected in order to perform histological analyses using light microscopy. The samples were fixed in formaldehyde and modified glutaraldehyde (glutaraldehyde 1\%; paraformaldehyde $4 \%$ in sodium phosphate buffer $-\mathrm{NaH}_{2} \mathrm{PO}_{4} \cdot \mathrm{H}_{2} \mathrm{O}$ at $0.1 \mathrm{M}$; pH 7.2) (KARNOVSKY, 1965). Subsequently, samples were submitted to two vacuum series $(-600 \mathrm{mmHg})$ for $30 \mathrm{~min}$ each. After that, samples were stored at $4^{\circ} \mathrm{C}$ for 30 days. Samples were then dehydrated in an ethanol series with increasing concentrations for $15 \mathrm{~min}$ in each solution ( 10 , $20,30,40,50,60,70,80,90$ and $100 \%, v / v)$. The samples were embedded with hydroxyethyl methacrylate resin
(Historesin, Leica ${ }^{\circledR}$, Hildeberg, Germany). The blocks containing the samples were prepared according to manufacturer's instructions, being stored for 28 days at $24^{\circ} \mathrm{C}$. The blocks containing the samples were sectioned longitudinally to a thickness of $10 \mu \mathrm{m}$ using an automatic rotary microtome Microm HM 355S (Thermo Scientific). The sections were stained with toluidine blue $(0.05 \%$, $\mathrm{v} / \mathrm{v}$ ) in a phosphate buffer and citric acid (SAKAI, 1973) for 20 min and mounted on slides with a synthetic resin $\left(\right.$ Entellan $\left.^{\circledR}\right)$. The slides were analyzed and photographed with a light microscope (Opton) and images were captured in micrometric scale.

\section{Data collection and statistical analysis}

The data collected from the two experiments were submitted to Hartley's test $(P<0.05)$ to verify the variance homogeneity among treatments and to Lilliefors's test $(P<0.05)$ to check for normal distribution. When necessary, the data were transformed through Box-Cox test. Thereafter, the data were submitted to ANOVA $(P<0.05)$. Post-hoc analyses with Tukey's test $(P<0.05)$ were performed when significance was detected by ANOVA. The software SOC (EMBRAPA, 1990) and packages from $R$ ( $R$ Development Core Team, 20I2) were used for the analyses.

\section{RESULTS}

\section{Cleft grafting}

The four combinations conducted for cleft grafting (scion/rootstock: K.A./S.M = K. anthotheca $+S$. macrophylla; S.M./K.A. = S. macrophylla + K. anthotheca; S.M./S.M = S. macrophylla + S. macrophylla; and K.A./ $\mathrm{K} . \mathrm{A} .=\mathrm{K}$. anthotheca $+K$. anthotheca) revealed different levels of compatibility (Figure 2), and, therefore, resulted in different survival frequencies. After 45 and 200 days, respectively, $6 \mathrm{I}$ and $48 \%$ of grafting success was obtained, 


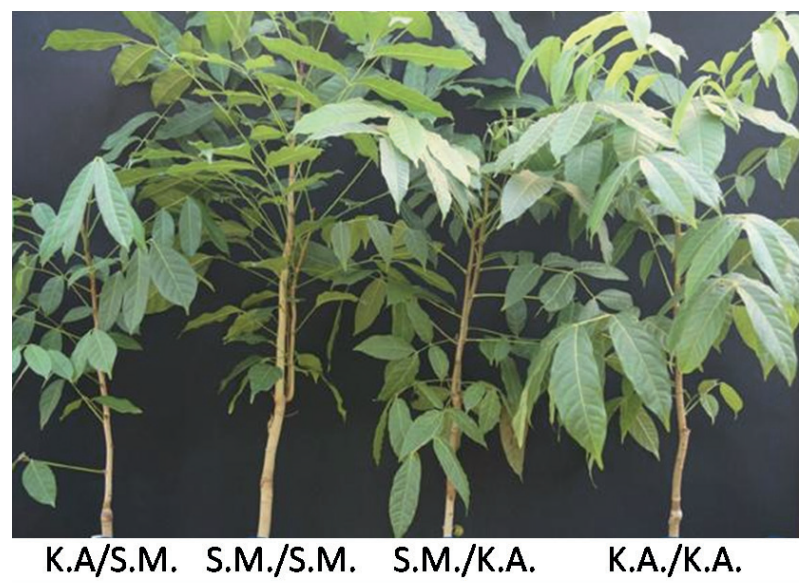

Scion/Rootstock

FIGURE 2 Grafts obtained through cleft grafting for interspecific and intraspecific combinations between rootstock and scion of Khaya anthotheca and Swietenia macrophylla (after 45 days of grafting). S.M./K.A: S. macrophylla + K. anthotheca; S.M./S.M. $=$ S. macrophylla + S. macrophylla; K.A./S.M. $=K$. anthotheca + S. macrophylla; and K.A./K.A. $=K$. anthotheca + K. anthotheca.

considering the whole set of grafts (Table 2). Interspecific grafting provided the lowest success after 200 days. No grafts from the combination S. macrophylla $+K$. anthotheca (scion/rootstock) survived, while $52 \%$ of the combination K. anthotheca + S. macrophylla (scion/rootstock) survived. Intraspecific grafts provided the highest survival, with $92 \%$ for $K$. anthotheca and $48 \%$ for S. macrophylla.

The grafting success was evidenced from histological sections of the region of the union between the scion and the rootstock (Figure 3A). The radius of scion and rootstock were aligned, which indicates that a connection between vascular tissues and parenchyma was established between the propagules (Figure 3B-D). The presence of vascular cambium, medulla and cortex evidenced the beginning of secondary growth.

TABLE 2 Grafting success of interspecific and intraspecific combinations of Khaya anthotheca and Swietenia macrophylla.

\begin{tabular}{ccc}
\hline $\begin{array}{c}\text { Cleft grafts } \\
\text { (Scion/Rootstock) }\end{array}$ & \multicolumn{2}{c}{ Grafting success (\%) } \\
\hline S. macrophylla/ & 35 days & 200 days \\
\hline $\begin{array}{c}\text { K. anthotheca (S.M./K.A.) } \\
\text { K. anthotheca/ }\end{array}$ & $36.0 \mathrm{~B}( \pm 9.8)$ & $0.0 \mathrm{C}( \pm 0.0)$ \\
$\begin{array}{c}\text { S. macrophylla (K.A./S.M.) } \\
\text { K. anthotheca/ }\end{array}$ & $56.0 \mathrm{~B}( \pm 10.1)$ & $52.0 \mathrm{~B}( \pm 10.2)$ \\
$\begin{array}{c}\text { K. anthotheca (K.A./K.A.) } \\
\text { S. macrophylla/ }\end{array}$ & $92.0 \mathrm{~A}( \pm 5.5)$ & $92.0 \mathrm{~A}( \pm 5.5)$ \\
S. macrophylla (S.M./S.M.) & 60.0AB $( \pm 10.0)$ & $48.0 \mathrm{~B}( \pm 10.2)$ \\
\hline
\end{tabular}

Means in the same column followed by the same letter show no difference by Tukey's. Data are presented as: mean ( \pm standard error).

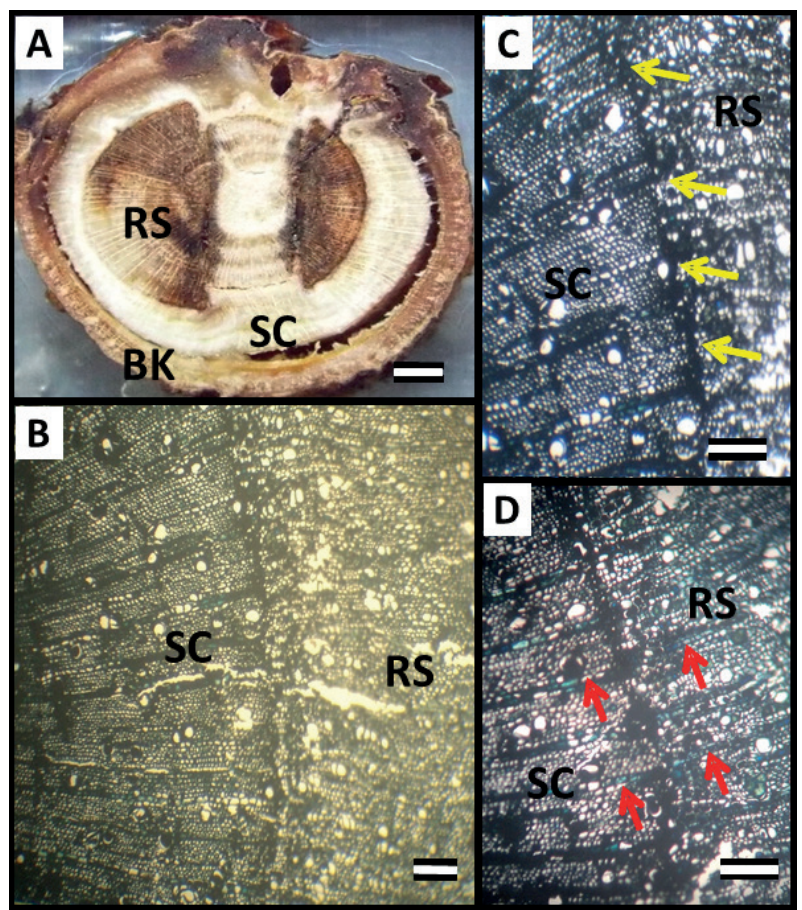

FIGURE 3 Histological sections of grafts between Swietenia macrophylla and Khaya anthotheca. A - Transversal profile of the stem at the union between $K$. anthotheca (scion) and S. macrophylla (rootstock). $B$ and C - Transverse profile of the grafting area indicating adhesion between tissues of the rootstock (yellow arrows at B) (S. macrophylla) and the scion ( $K$. anthotheca). D - Connection between the parenchyma tissue of the rootstock and scion (red arrows). $\mathrm{RS}=$ rootstock; $\mathrm{SC}=$ scion; $\mathrm{BK}=$ bark. Bars represent $0.1 \mathrm{~cm}$ in $\mathrm{A}$ and $10.0 \mu \mathrm{m}$ in $\mathrm{B}, \mathrm{C}$ and $\mathrm{D}$.

\section{Air layering}

The adventitious rooting and callogenesis of the air layers of $K$. anthotheca were affected (ANOVA, $P<0.05$ ) by the different nutrient solutions and the application of indole-3-butyric acid (IBA) (Tables 3 and $4)$, but no interaction between nutrient solution and IBA was detected. Rooting was the highest when the air layers were treated with solution containing $100 \%$

TABLE 3 Percentage of adventitious rooting and callogenesis in air layers of Khaya anthotheca treated with different concentrations of nutrient solutions independent of IBA application.

\begin{tabular}{ccc}
\hline Nutrient solution* & $\begin{array}{c}\text { Adventitious rooting } \\
(\%)\end{array}$ & $\begin{array}{c}\text { Callogenesis } \\
(\%)\end{array}$ \\
\hline $\mathrm{S}_{100}$ & $75.0 \mathrm{~A}( \pm 7.3)$ & $22.2 \mathrm{~B}( \pm 7.0)$ \\
$\mathrm{S}_{50}$ & $69.4 \mathrm{AB}( \pm 7.8)$ & $25.0 \mathrm{~B}( \pm 7.3)$ \\
$\mathrm{S}_{25}$ & $55.5 \mathrm{~B}( \pm 8.4)$ & $41.7 \mathrm{~A}( \pm 8.3)$ \\
\hline
\end{tabular}

$* S_{100}=100 \%$ of the original concentration of macro and micronutrients; $S_{50}=$ $50 \%$ of the original concentration; and $\mathrm{S}_{25}=25 \%$ of the original concentration. In columns, mean values followed by the same capital letter show no difference between nutrient solution concentrations based on Tukey's test. Data are presented as: mean ( \pm standard error). 
TABLE 4 Percentage of adventitious rooting and callogenesis in air layers of Khaya anthotheca treated with different concentrations of indole-3-butyric acid (IBA) independent from the nutrient solution.

\begin{tabular}{ccc}
\hline $\begin{array}{c}\text { IBA } \\
\left(\mathrm{g} . \mathrm{L}^{-1}\right)\end{array}$ & $\begin{array}{c}\text { Adventitious rooting } \\
(\%)\end{array}$ & $\begin{array}{c}\text { Callogenesis } \\
(\%)\end{array}$ \\
\hline 0.0 & $16.7^{\mathrm{B}}( \pm 6.3)$ & $77.8^{\mathrm{A}}( \pm 7.1)$ \\
3.0 & $94.4^{\mathrm{A}}( \pm 3.8)$ & $2.8^{\mathrm{B}}( \pm 2.8)$ \\
8.0 & $88.9^{\mathrm{A}}( \pm 5.3)$ & $8.3^{\mathrm{B}}( \pm 4.7)$ \\
\hline
\end{tabular}

Means in the same column followed by the same letter show no difference by Tukey's. Data are presented as: mean ( \pm standard error).

$\left(\mathrm{S}_{100}\right)$ and $50 \%\left(\mathrm{~S}_{50}\right)$ of the concentration of macro and micronutrients of the reference solution (Table I). The proportions of rooting diminished by $20 \%$ when the solution with only $25 \%\left(\mathrm{~S}_{25}\right)$ of the original concentration was used in the irrigation process. Conversely, the occurrence of callogenesis was higher with $\mathrm{S}_{25}$ treatment (Table 3).

The adventitious rooting was higher when IBA was applied (3.0 and $\left.8.0 \mathrm{~g} \cdot \mathrm{L}^{-1}\right)$ (Table 4). However, no significant difference was detected between the two IBA concentrations for this variable. Nevertheless, the adventitious rooting was $72 \%$ higher in IBA-treated plants than in non-treated plants $\left(0.0 \mathrm{~g} \cdot \mathrm{L}^{-1}\right)$. Callus proliferation was $70 \%$ higher in the absence of the auxin (Table 4). In general, the application of the nutrient solution at $100 \%$ or $50 \%$ concentration along with IBA (3.0 or $8 \mathrm{~g} \cdot \mathrm{L}^{-1}$ ) are recommended treatments for optimal adventitious rooting from air layers of $K$. anthotheca (Figure 4).
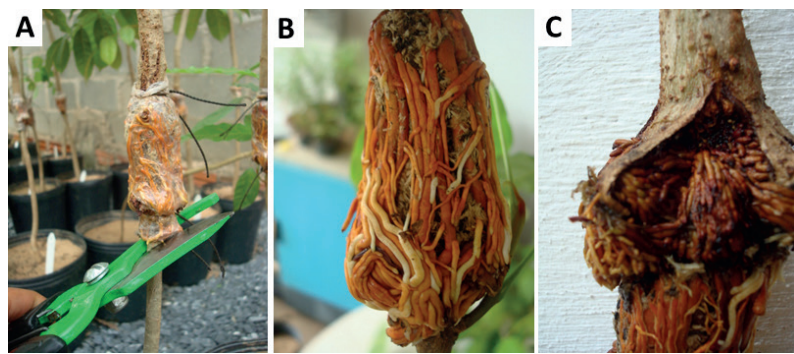

FIGURE 4 Air layers of Khaya anthotheca. A - Detachment of the air layer from the plant. Air layers treated with $(B)$ 3.0 and (C) $8.0 \mathrm{~g} \cdot \mathrm{L}^{-1}$ of indole-3-butyric acid (IBA)

\section{DISCUSSION}

\section{Cleft grafting}

This is the first description of vegetative propagation of $K$. anthotheca through grafting and air layering for vegetative propagation in nurseries. Moreover, it is the first report of interspecific grafting between $K$. anthotheca and S. macrophylla. Our data revealed that intraspecific grafting (scion / rootstock: K. anthotheca /
K. anthotheca and S. macrophylla/S. macrophylla) was, in general, compatible. Conversely, interspecific grafting resulted in high incompatibility, when $K$. anthotheca was used as rootstock and S. macrophylla as scion, ultimately providing no compatibility after 200 days (Table 2). On the contrary, when $K$. anthotheca was used as scion and S. macrophylla as rootstock, $52 \%$ of grafts survived after 200 days (Table 2). The histologic analyses reinforced that the compatibility was effective, since vascular tissue regeneration was observed (Figure 3 ).

The complete incompatibility when S. macrophylla was used as scion was also found previously with interspecific grafting with the related mahogany $K$. ivorensis as rootstock (PINHEIRO et al., 20II). The events related to such incompatibility are still awaiting understanding. It has been suggested that they might be related to nutrient deficiencies, differential tissue-growth potential between scion and rootstock and the presence of parenchyma or bark tissue around the adhesion area (HARTMANN et al., 20I I).

From our analyses, we recommend using grafting of $K$. anthotheca, which might be efficient at the intraspecific level, and might be performed interspecifically with S. macrophylla. However, the inverse combination with $K$. anthotheca as the rootstock and S. macrophylla as the scion is incompatible. Such incompatibility might be associated with morphological, physiological and molecular factors. The size of the cells of the two different parts (scion and rootstock) could be a limiting factor, as well as the exchange of liquids and metabolites between them. A comprehensive analysis of their molecular implications (genomic, transcriptomic, proteomic and metabolomic profiles) is encouraged for further assessments.

\section{Air layering}

Concerning air layering, our results evidenced it as a suitable method for the vegetative propagation of $K$. anthotheca. A critical factor in determining adventitious rooting was the application of a nutrient solution with at least $50 \%$ of the macro and micronutrients concentrations proposed by Brondani et al. (2014) (Table 3). Moreover, the application of IBA improved adventitious rooting. A number of studies have shown increased adventitious rooting with IBA, such as in Bixa orellana (MANTOVANI et al., 20I0), Syzygium jambos (MARTINS; ANTUNES, 2000), Vitis rotundifoliae (PACHECO et al., 1998) and Prunus persica (CASTRO; SILVEIRA, 2003). Our data also showed that IBA ( 3.0 or $8 \mathrm{~g} \cdot \mathrm{L}^{-1}$ ) promoted higher rates of adventitious rooting than callogenesis (Figure 4 and Table 
4), for plants originating from seeds. Similar results were observed by Castro and Silveira (2003), who achieved high rates of adventitious rooting with air layers of $P$. persica treated with $3.0 \mathrm{~g} \cdot \mathrm{L}^{-1}$ of IBA.

We recommend using the nutrient solution of Brondani et al. (2014) with at least $50 \%$ of their proposed macro and micronutrients concentrations in combination with IBA ( 3.0 or $8 \mathrm{~g} \cdot \mathrm{L}^{-1}$ ) to provide optimal adventitious rooting during air layering of $K$. anthotheca.

\section{Implications of the results}

The use of cleft grafting and air layering have important implications for expanding the production of $K$. anthotheca in nurseries. First, cleft grafting has the potential to rescue superior genotypes selected for a breeding program. The grafts may be used to establish a seed orchard to produce seeds from desired genetic materials. The grafts may also be used as a source of propagules for the vegetative propagation of $K$. anthotheca by cuttings and mini-cuttings or even micropropagation.

Another potential application of cleft grafting is the production of S. macrophylla in homogeneous plantations. Using $K$. anthotheca as rootstock might have a positive effect on the growth of the trees in the field, since somehow it might confer an induced resistance to $H$. grandella (LINZ et al., 2009). Such a propagation strategy has already been tested by Kalil Filho et al. (2000), with combinations of scion and rootstock between Toona ciliata and S. macrophylla. However, no compatibility occurred between the genotypes, leading to their death. In a different approach, Perez et al. (20 I0a) evaluated different combinations of scion and rootstock ( $K$. senegalensis and Toona ciliata) for the propagation of $S$. macrophylla and $C$. odorata, aimed at resistance to $H$. grandella. Those combinations improved the resistance to the insect, however, further recommendation has been given to study such effects on more advanced stages of the trees and in field conditions. Moreover, extracts prepared from plants resistant to $H$. grandella confirmed the possibility of inducing resistance through grafting in S. macrophylla (PEREZ et al., 20I0b). Such results reinforce the usefulness of this method for the propagation of the species when the aim is to establish homogeneous plantations.

Induced resistance by grafting is desirable, as $H$. grandella bores the apical meristem of S. macrophylla in nurseries and trees in the field (LUNZ et al., 2009). Such injury leads to the breakdown of apical dominance and reduction in growth and wood quality. Moreover, it might generate a twisted trunk and the presence of nodes, along with other undesirable effects, which decrease the value of the wood in the market (OHASHI et al., 2008; LUNZ et al., 2009; ROCHA et al., 20l6). As no evidence of $H$. grandella attack on $K$. anthotheca has been reported so far, the crown replacement by using $K$. anthotheca as scion could be an alternative for obtaining high-quality wood in homogeneous planting of S. macrophylla. Contrarily, the opposite approach, which would be desirable, is still problematic. Our results showed no compatibility between S. macrophylla (scion) and $K$. anthotheca (rootstock), which compromises the production of wood from S. macrophylla (as scion) in homogeneous plantations based on the theory of induced resistance to the attack of $H$. grandella (LINZ et al., 2009). Either way, such possibilities require further experimental evidence.

The air layering technique was proved an effective method for adventitious rooting of $K$. anthotheca. Although it is a laborious method at the initial stage with all the preparation steps from girdling to covering and maintenance of the substrate moisture, it might be an alternative method for rescuing valuable genotypes, with the potential to obtaining several propagules from a single tree, when necessary.

Overall, both cleft grafting and air layering might be used to compose a minigarden (seminal or clonal) of $K$. anthotheca, which would be aimed at the production of new plants from mini-cuttings. Such strategies allow the production of new plants throughout the entire year, and most importantly, require no seeds.

\section{CONCLUSIONS}

We have demonstrated the application of clef grafting and air layering for vegetative propagation of $K$. anthotheca. Both methods constitute a good alternative for the propagation of the species. Graft compatibility was observed at the intraspecific as well as interspecific level with S. macrophylla. However, the only interspecific combination that resulted in a compatible graft was $K$. anthotheca as the scion and S. macrophylla as the rootstock. The other combination requires further study for improving compatibility and survival of the grafts. In the case of air layering, the combination of a nutrient solution with at least $50 \%$ of the original concentration described and the application of IBA (3.0 or $8 \mathrm{~g} . \mathrm{L}^{-1}$ ) were important for providing high adventitious rooting of $K$. anthotheca.

\section{ACKNOWLEDGMENTS}

We are grateful to the National Council for Scientific and Technological Development (CNPq) and the Coordination for the Improvement of Higher Level Personnel (CAPES), both from Brazil, for their financial support. 


\section{REFERENCES}

ALVARES, C. A.; STAPE, J. L.; SENTELHAS, P. C.; GONÇALVES, J. L. M.; SPAROVEK, G. Köppen's climate classification map for Brazil. Meteorologische Zeitschrift, v. 22, n. 6, p. 7II-728, 2013.

BRONDANI, G. E.; BACCARIN, F. J. B.; BERGONCI, T.; GONÇALVES, A. N.; ALMEIDA, M. Miniestaquia de Eucalyptus benthamii: efeito do genótipo, AIB, zinco, boro e coletas de brotações. Cerne, v. 20, n. I, p. I47-I56, 2014.

BRITWUM, S. P. K. Notes on air-layering in Cedrela odorata and Terminalia ivorensis. Technical Newsletter. Forest Products Research Institute, v. 4, n. 3, p. I I- I3, 1970.

CASTRO, L. A. S.; SILVEIRA, C. A. P. Propagação vegetativa do pessegueiro por alporquia. Revista Brasileira de Fruticultura, v. 25, n. 2, p. 368-370, 2003.

CORNELIUS, J. P. The effectiveness of pruning in mitigating Hypsipyla grandella attack on young mahogany (Swietenia macrophylla King) trees. Forest Ecology and Management, v. I48, n. I-3, p. 287-289, 200 I.

DANTHU, P.; DIAITÉ-SANOGO, D.; SAGNA, M.; SAGNA, P.; DIA-GASSAMA, Y. K. Micropropagation of Khaya senegalensis, an African mahogany from dry tropical zones. Journal of Tropical Forest Science, v. I5, n. I, p. 164- 175, 2003.

DEGEN, B.; WARD, S. E.; LEMES, M. R.; NAVARRO, C.; CAVERS, S.; SEBBEN, A. M. Verifying the geographic origin of mahogany (Swietenia macrophylla King) with DNAfingerprints. Forensic Science International Genetics, v. 7, n. I, p. 55-62, 2013.

EMBRAPA. Empresa Brasileira de Pesquisa Agropecuária. Programa SOC - software científico: versão 2.1. Campinas: Embrapa Informática Agropecuária, 1990.

FRANÇA, T. S. F. A.; ARANTES, M. D. C.; PAES, J. B.; VIDAURRE, G. B.; OLIVEIRA, J. T. S.; BARAÚNA, E. E. P. Características anatômicas e propriedades físico-mecânicas das madeiras de duas espécies de mogno africano. Cerne, v. 21 , n. 4, p. 633-640, 2015.

GROGAN, J.; LOVELESS, M. D. Flowering phenology and its implications for management of big-leaf mahogany Swietenia macrophylla in Brazilian Amazonia. American Journal of Botany, v. I00, n. I I, p. 2293-2305, 2013.

HARTMANN, H. T.; KESTER, D. E.; DAVIES JR, F. T.; GENEVE, R. L. Plant propagation: principles and practices. $8^{\text {th }}$ ed. Prentice- Hall, 201 I. 915 p.

KAlil FILHO, A. N.; HOFfMAN, H. A. Propagação vegetativa por enxertia em meliáceas. Circular Técnica 16I, Embrapa, 2008. 3 p.

KALIL FILHO, A. N.; HOFFMANN, H. A.; GRAÇA, M. E. C.; TAVARES, F. R. Enxertia de mogno em toona para a indução de resistência à Hypsipyla grandella (Zeller, 1948) no mogno sul-americano (Swietenia macrophylla). Boletim de Pesquisa Florestal, n. 4I, p. 74-78, 2000.
KARNOVSKY, M. J. A formaldehyde-glutaraldehyde fixative of high osmolality for use in electron microscopy. Journal of Cell Biology, v. 27, n. 4, p. I37-138, 1965.

LEE, S. E.; KIM, M. R.; KIM, J. H.; TAKEOKA, G. R.; KIM, T. W.; PARK, B. S. Antimalarial activity of anthothecol derived from Khaya anthotheca (Meliaceae). Phytomedicine, v. I5, n. 6-7, p. 533-535, 2008.

LUNZ, A. M.; THOMAZINI, M. J.; MORAES, M. C. B; NEVES, E. J. M; BATISTA, T. F. C.; DEGENHARDT, J.; SOUSA, L. A.; OHASHI, O. S. Hypsipyla grandella em mogno (Swietenia macrophylla): situação atual e perspectivas. Pesquisa Florestal Brasileira, n. 9, p. 45-55, 2009.

MANTOVANI, N. C.; GRANDO, F. M.; XAVIER, A.; OTONI, C. W. Resgate vegetativo por alporquia de genótipos adultos de urucum (Bixa orellana L.). Ciência Florestal, v. 20, n. 3, p. 403-410, 2010.

MARTINS, A. B. G.; ANTUNES, E. L. Propagação do jambeiro rosa (Sizigyum jambos L. Alston.) pelo processo de alporquia. Revista Brasileira de Fruticultura, v. 22, n. 2, p. 205-207, 2000.

MOREIRA, X.; ABDALA-ROBERTS, L.; PARRA-TABLA, V.; MOONEY, K. A. Positive effects of plant genotypic and species diversity anti-herbivore defenses in a tropical tree species. Plos One, v. 9, n. 8, el05438, 2014.

MOYO, P.; BOTHA, M. E.; NONDABA, S.; NIEMAND, J.; MAHARAJ, V. J.; ELOFF, J. N.; LOUW, A. I.; BIRKHOLTZ, L. In vitro inhibition of Plasmodium falciparum early and late stage gametocyte viability by extracts from eight traditionally used South African plant species. Journal of Ethnopharmacoly, v. 185, n. 5, p. 235-242, 2016.

NIKLES, D. G.; BEVEGE, D. I.; DICKINSON, G. R.; GRIFFITHS, M. H.; REILLY, D. F.; LEE, D. J. Developing African mahogany (Khaya senegalensis) germplasm and its management for a sustainable forest plantation industry in northern Australia: progress and needs. Australian Forestry, v. 7I, n. I, p. 33-47, 2008.

OBBO, C. J. D.; MAKANGA, B.; MULHOLLAND, D. A.; COOMBES, P. H.; BRUN, R. Antiprotozoal activity of Khaya anthotheca (Welv.) C.D.C. a plant used by chimpanzees for self-medication. Journal of Ethnopharmacology, v. I47, n. I, p. 220-223, 2013.

OHASHI, O. S.; SILVA, J. N. M.; SILVA, M. F. G. F.; COSTA, M. S. S.; SARMENTO JR., R. G.; SANTOS, E. B.; ALVES, M. Z. N.; PESSOA, A. M. C.; SILVA, T. C. O.; BITTENCOURT, P. R. G.; BARBOSA, T. C.; SANTOS, T. M. Manejo Integrado da broca do mogno Hypsipyla grandella Zeller (Lep. Pyralidae). EMBRAPA/FCAP, 2008. 33 p.

OPUNI-FRIMPONG, E.; KARNOSKY, D. F.; STORER, A. J.; COBBINAH, J. R. Key roles of leaves, stockplant age, and auxin concentration in vegetative propagation of two African mahoganies: Khaya anthotheca Welw. and Khaya ivorensis A. Chev. New Forests, v. 36, n. 2, p. II5-I 23, 2008. 
PACHECO, A. C.; CASTRO, P. R. C.; GLÓRIA, B. A. Aspectos anatômicos do enraizamento da videira muscadínias (Vitis rotundifolia Michx) através de alporquia. Scientia Agrícola, v. 55 , n. 2, p. $210-217,1998$.

PEREZ, J.; EIGENBRODE, S. D.; HILJE, L.; TRIPEPI, R. R.; AGUILAR, M. E.; MESEN, F. Use of grafting to prevent Hypsipyla grandella (Zeller) (Lepidoptera: Pyralidae) damage to new world Meliaceae species. Neotropical Entomology, v. 39, n. 4, p. 6I8-625, 2010a.

PEREZ, J.; EIGENBRODE, S.; HILJE, L.; TRIPEPI, R.; AGUILAR, M. E.; MESÉN, F. Leaves from grafted Meliaceae species affect survival and performance of Hypsipyla grandella (Zeller) (Lepidoptera: Pyralidae) larvae. Journal of Pest Science, v. 83, n. 2, p. 95-104, 2010 b.

PINHEIRO, A. L.; COUTO, L.; PINHEIRO, D. T.; BRUNETTA, J. M. F. C. Ecologia, silvicultura e tecnologia de utilização dos mognos - africanos (Khaya spp.). Sociedade Brasileira de Agrossilvicultura - SBAG, 20II. 102 p.

ROCHA, K. J.; CALDEIRA, S. F; BRONDANI, G. E. Development of Swietenia macrophylla in escape areas. Scientia Forestalis, v. 44, n. II0, p. 28I-29I, 2016.

R Development Core Team. An introduction to R. Notes on R: a programming environment for data analysis and graphics. Version 2.I5.I.R Foundation for Statistical Computing, Vienna, Austria. ISBN 3-90005 I-I2-7. 2012.
SAKAI, W. S. Simple method for differential staining of parafilm embedded plant material using toluidine blue. Stain Technology, v. 48, n. 5, p. 247-249, 1973.

SULEIMAN, M. M.; BAGLA, V.; NAIDOO, V.; ELOFF, J. $\mathrm{N}$. Evaluation of selected South African plant species for antioxidant, antiplatelet, and cytotoxic activity. Pharmaceutical Biology, v. 48, n. 6, p. 643-650, 2010.

SULEIMANA, M. M.; McGAW, L. J.; NAIDOO, V.; ELOFF, J. N. Detection of antimicrobial compounds by bioautography of different extracts of leaves of selected South African tree species. African Journal of Traditional, Complementary and Alternative Medicine, v. 7, n. I, p. 64-78, 2009.

VERMA, R. K.; YU, W.; SINGH, S. P.; SHANKAR, S.; SRIVASTAVA, R. K. Anthothecol-encapsulated PLGA nanoparticles inhibit pancreatic cancer stem cell growth by modulating sonic hedgehog pathway. Nanomedicine, v. II, n. 8, p. 206I-2070, 2015.

WHITMORE, T. C. Mahogany: tree of the future. In: Lugo AE, Figueroa-Colon JC, Alayón M (Ed.) Big-Leaf mahogany: genetic, ecology, and management. Ecological studies. Springer Verlag, 2003. p. I-5. 
